\title{
Training Employees to Be a Source of Sustained Competitive Advantage
}

\author{
Paul J. Davis \\ Kazakh British Technical University
}

The purpose of this paper is to demonstrate that there is an important role for learning and development professionals in helping the firm achieve Sustained Competitive Advantage (SCA) and, furthermore, to explain how this can be achieved. This hypothesis is developed through an extensive review of the scholarly literature and leads to the formulation of a practitioner's guide for learning and development professionals. The study finds that employees can be a direct source of SCA for their firm by applying Resource-based Theory (RBT) through employee training and development initiatives and programs. The research findings are limited in that the paper is conceptual and while a great deal of evidence exists to support its central premise, the hypothesis is yet to be tested through empirical research. There are important practical implications of the study for learning and development specialists and consultants, for employees, human resource professionals, organizational strategic planners and organizations at large. Specifically, the paper points toward new directions for learning strategy. This paper has originality in that it appears to be the first to explicitly link the practical application of RBT with employee training and development initiatives and to provide examples of how this can be achieved.

Keywords: Training, Competitive Advantage, Learning and Development, Resource-based Theory, HR strategy

\section{INTRODUCTION}

Pick up any mainstream university textbook on business strategy and notice a singular view being perpetuated regarding firm competitive advantage (CA). This view is that sustained competitive advantage (SCA) is manufactured externally rather than from within the firm. The most celebrated proponent of this view is Michael Porter (1980; 1985). Porter's ubiquitous Five Forces Model contends that firms derive competitive advantage through the strategic development and positioning of factors external to the inner workings of the business. Porter focuses on customers; suppliers; products; branding; supply chain and numerous other external variables to explain how firms build and sustain CA. A chorus of other experts subscribe to the same theory and so it has become embedded in strategic management courses as the explanation of competitive advantage. To a very significant degree, the internal assets of the firm have had their importance as a wealth-generating, competitive advantage sidelined. This is somewhat curious as firms all over the globe trumpet the central importance of their employees to their business. Indeed, "our employees are our greatest asset" has become such a standard of executive rhetoric that its pervasiveness has rendered it a cliché. 
While there is no doubt that external factors contribute significantly to the firm's ability to achieve SCA, it is only half the story. Organizations that fix their gaze resolutely outwards do so at their peril because they are overlooking the valuable internal resources at their fingertips; specifically, their people. Employees are only merely units of production if they are thought of in that way. A more strategic, longterm view would be to see employees for what they really are: a highly valuable differentiated resource.

\section{THE HYPOTHESIS}

This paper cultivates the hypothesis that employees can be developed to become a direct source of SCA for the firm through the practical application of Resource-based Theory (RBT) and that training and development professionals are at the vanguard of such a strategy. Training professionals, through the design and delivery of development programs, can translate RBT into practice. Into actions; mindsets; attitudes and behaviors that return real value to the firm and which maximize the value of the firm's external positioning.

While there is evidence, and arguably widespread acknowledgment, that employee competencies such as knowledge and skills can be a source of competitive advantage for a firm, very little has been explicitly stated as to how one translates to the other. Ulrich (1991) argued precisely this but did not reference RBT at all and provided no analysis of how human competencies can translate to competitive advantage. Wright et., al. (1992) explained employee competencies in terms of competitive advantage following the RBT approach, but there lacked any specific examples helpful to practitioners. Indeed, one of the most common criticisms of RBT in the literature is that RBT fails to explain how resources are developed; how they evolve from simply existing to becoming a source of SCA (Stinchcombe, 2000). Similar and related criticisms regarding the problems translating RBT into practice have been consistently made (Kraaijenbrink et., al. 2010; Akio, 2005; Fahy, 2000).

This paper closes the circle by focusing RBT on practice and the training and development practitioner. In so doing, this paper provides practical suggestions to training professionals seeking to develop employees with skill sets that go beyond doing the job and reach into extracting advantage for the firm in the marketplace. Before looking at this; some important definitions.

\section{LITERATURE REVIEW}

\section{What Is a Resource?}

TABLE 1

\section{CATEGORIES OF INTERNAL FIRM RESOURCES}

\begin{tabular}{lll}
\hline Physical Capital & Human Capital & Organizational Capital \\
\hline - Technology & $\bullet$ Training & $\bullet$ organizational structure \\
- Plant & $\bullet$ Employee: knowledge; skills; & $\bullet$ Systems and controls \\
- Machinery & effort; behaviors; creativity; & $\bullet$ Processes and procedures \\
- Other equipment & innovation; insight; & $\bullet$ Policies \\
- Location & intelligence; networks; work; & $\bullet$ Communication \\
- Buildings & loyalty; initiative; attitudes; & $\bullet$ Planning \\
- Materials/stock & qualifications & $\bullet$ IT infrastructure \\
- Furniture; furnishings & & $\bullet$ \\
\hline
\end{tabular}

In terms of RBT, firm resources include all internal assets, capabilities and competencies under the control of the firm and applied for the purpose of achieving strategic objectives. Arguably, chief among these are employees and their knowledge and skills (Grant, 1991) although Barney (1991) highlights three distinct categories of resources: Physical Capital; Human Capital and Organizational Capital. Table 1 highlights which firm resources fall into each category. 
These resources may not all be strategically relevant, and may not all be sources of SCA for the firm, but they are all potential sources of SCA. A good example would be firm location. If a business owner opens a bakery opposite a major suburban train station, attracting the morning and evening city commuters, then clearly location becomes a strategic advantage (if leveraged) over a competitor located in a back street and out of sight. This paper will demonstrate that precisely the same rule applies to the firm's employees and their skills and knowledge.

\section{What Is Competitive Advantage?}

According to Barney (1991), a firm can be said to have a CA when it is following a strategy that: creates value; is not being implemented by competitors; cannot have returns of the strategy duplicated by competitors. In this sense, Barney is essentially highlighting the importance of uniqueness because uniqueness is a differentiator.

\section{What Is Sustained Competitive Advantage?}

The common interpretation of 'sustained' in terms of CA, and the interpretation favored by Porter (1985) is that it means a CA that lasts a long time. The problem with this definition is self-evident; how long is long? At what point in time does a CA become sustained? And, how do we know? It is rather difficult to say, and one person's arbitrary definition will surely be contested by another's. Therefore a time-framed measurement of CA does not really work. A preferable interpretation, one favored by RBT, is, as Rumelt (1984) argued, CA is sustained only if it continues after competitors have failed and ceased to attempt to copy it. An imperfect definition, but workable.

\section{What Is Resource-based Theory (RBT)?}

RBT is a theoretical model of the firm for strategic human resource management. Ultimately, at its core, it is knowledge-based theory of the firm (Sveiby, 2001). It proposes that a firm's internal resources can potentially become a direct source of SCA as long as they: a) meet certain criteria; b) are heterogeneous; c) are immobile; d) are deployed and/or applied skillfully. RBT, then, places the focus on generating SCA internally rather than externally; on resources rather than products or, as Wright and McMahan (1992) put it, on the firm rather than the industry.

RBT proper begins with Wernerfelt (1984) who first analyzed firm competitiveness from the perspective of its internal resources, including the skills and knowledge of employees. Prior to this, competitiveness had only been analyzed from a product-centered, external perspective. Reflecting on his award-winning paper ten years later, Wernerfelt (1995) argued more strongly for a Resource-based view of the firm saying that strategies which are not resource-based cannot work in competitive environments. He noted that in business a firm is always competing against the best in whatever market it operates in because weaker competition is forced out. Wernerfelt concluded his paper by saying that RBT should not be a choice but the default approach to developing competitive business strategy.

Wernerfelt's view is notable for its Darwinian overtones with RBT essentially being the firm's DNA in action. In a competitive business environment, as in nature, only the fittest and strongest will ultimately survive over time. Those firms that do survive and thrive must kill off the weaker competition through leveraging their competitive advantage through the application of RBT.

Other influential contributors to RBT in the early period include Barney (1986) who proposed that organizational culture could be a source of sustained competitive advantage. A very distinct departure from product-based explanations of SCA. Organizational culture can have the ability to drive competitive advantage through the inculcation of shared values such as risk taking or cooperation. Conner (1991) compared RBT with five other classical theories of the firm and concluded that RBT does represent a new, distinct theory of the firm. While Grant (1991) developed a new strategy formulation framework based upon RBT which was focused on developing competitive strength through capabilities.

Perhaps the most important of the early writing on RBT was Barney's 1991 contribution where the author challenged the Porter view of SCA at length and asserted that firms in the same competitive space can develop and maintain differentiated resources and that these resources can be a source of SCA. 
Barney also devised the criteria against which a resource can be assessed to judge whether it has the potential to be a source of SCA. Barney set out four qualities a resource must possess:

1. Must be valuable - can exploit opportunities and negate threats

2. Must be rare - hard for competitors to easily acquire

3. Must be imperfectly imitable - cannot be copied in an exact form

4. Must be non- substitutable - something different but similar cannot be used in its place This is commonly expressed in the literature as the following equation:

$$
\underline{\mathrm{V}+\mathrm{R}+\mathrm{I}+\mathrm{N}}
$$

$\mathrm{O}$

(Valuable; rare; imperfectly imitable; non-substitutable with the organization in place to apply them). 'Having the organization in place' means that the organization's systems, procedures, policies, structure and all other operational elements must be organized and aligned in ways which support internal resources being able to be used strategically. Chew et. al., (2008) call this the process of organizing resources into capabilities. Resources themselves, the authors claim, only have the potential to create SCA but need to become organizational capabilities before they can add value. Therefore, it is incumbent upon the firm to be able to recognize exactly how to leverage and organize the resources they have. Resources are malleable rather than inflexible and responsive to adaption. The example of the bakery given earlier highlights this. Having an excellent location beside the train station is a potential source of competitive advantage, but it must be acted upon to be realized. The bakery proprietor must, for example, be baking and open early to catch the morning commuters. If he opens his bakery at 9am then the potential of his location will be squandered.

\section{Resource-based Theory in the Literature}

The applications of RBT know no bounds. The theory has been applied to explaining Lord Nelson's victory at the Battle of Trafalgar (Pringle \& Kroll, 1997) to elucidating why Bayern München Football Club has enjoyed so much success (Bar-Eli, et. al., 2008) and, this year, the success of the top soccer clubs globally (da Costa, et. al., 2018). Winning at battle or at soccer is similar to winning in business when analyzed through the lens of RBT. In all cases the difference is the full utilization of the resources at hand and understanding how to translate the resource (a very gifted footballer, for example) into an advantage on the field through his capabilities. Most attention, though, has been given over to better understanding how RBT can enable business. Writing under the constraint of a few thousand words, a less wordy, abridged literature review is provided here (Table 2) in the form of a summary of the most pertinent contributions to the RBT literature. 
TABLE 2

SAMPLE OF ACADEMIC STUDIES APPLYING RBT AS THE THEORETICAL INVESTIGATIVE LENS 1996-2018

\begin{tabular}{|c|c|}
\hline Authors and publication date & General research topic \\
\hline $\begin{array}{l}\text { Hunt \& Madhavaram (2012); Knott (2009); Shook et., } \\
\text { al. (2009); Ordanini \& Rubera (2008); Sveiby (2001) }\end{array}$ & Strategic decision making \\
\hline Pertrusa-Ortega et., al. (2010) & Organizational structure \\
\hline Olavarrieta \& Ellinger (1997) & Logistics \\
\hline Bourne et., al. (2003); Das \& Teng (2000) & Operations management \\
\hline Lorentz et., al. (2018) & International purchasing and supply \\
\hline Wang et., al. (2018) & Project teams and open-source projects \\
\hline Hunt \& Derozier (2004) & Marketing strategy \\
\hline Wickramasinghe (2012); Ooi et., al. (2009) & Integration of HRM with TQM \\
\hline Jack et., al. (2006) & Service quality \\
\hline Alas \& Sun (2007) & Change management and employee attitudes \\
\hline Lewis et., al. (2010) & Product development \\
\hline $\begin{array}{l}\text { Cassia \& Minola (2012); Zubac et., al. (2012); Ellis- } \\
\text { Chadwick et., al. (2007) }\end{array}$ & Business development \& revenue generation \\
\hline Wan et., al. (2011) & Business diversification \\
\hline Mitra et., al. (2018); Hazen \& Byrd (2012) & Development and maintenance of IT systems \\
\hline $\begin{array}{l}\text { Campbell \& Park (2017); Gallego-Alvarez et., al. } \\
\text { (2011); McWilliams \& Siegel (2011) }\end{array}$ & Corporate Social Responsibility \\
\hline Davis \& Hasse (1999); Smith et., al. (1996) & Workplace learning \\
\hline Mugera (2012) & Human resource management \\
\hline Zhao \& Fan (2018) & Open government data sharing \\
\hline $\begin{array}{l}\text { Bollinger \& Smith (2001); Weissenberger-Eibel \& } \\
\text { Schenk (2009) }\end{array}$ & Knowledge management \\
\hline Andersen (2012) & Entrepreneurship \\
\hline Abhayawansa \& Abeysekera (2008) & Human capital reporting on financial statements \\
\hline $\begin{array}{l}\text { Xu et., al. (2014); Lo (2012); Masakure et., al. (2009); } \\
\text { Furrer et., al. (2008) }\end{array}$ & Firm performance \\
\hline Menguc \& Barker (2005) & Developing sales skills \\
\hline Khandekar \& Sharma (2005) & Organizational performance \\
\hline Yang \& Conrad (2011) & Diversity management \\
\hline
\end{tabular}

\section{Applying RBT to Learning and Development: A Practitioner's Guide}

Leiblein (2011) has observed that RBT is premised upon two observable truths. Firstly, firms vary in their ability to control, access and organize productive resources. Secondly, firms' differences in resources and resource management at least partially explain performance differences among close competitors. As this relates to a firm's learning and development function it is easy to see how Leiblein's observations might manifest. A firm, for example, that ensures all of its learning staff have a minimum qualification relevant to adult education and that the firm's learning resources are regularly reviewed and updated would be applying RBT for competitive advantage. A competing firm that did not validate the quality of its trainers and resources would be in a weaker competitive position.

The nature of learning resources and how those resources are managed can be controlled through the design and delivery of learning programs. Applying RBT to learning and development or training design and delivery means that training initiatives must adhere to the $\mathrm{V}, \mathrm{R}, \mathrm{I}, \mathrm{N}$ criteria that defines a resource which is capable of achieving SCA for the firm. By developing learning and development initiatives which are valuable, rare, not easily copied and not substitutable by something similar which would return the same results, training specialists would be contributing to building a workforce which itself is a source of SCA for the firm. 
It should be noted that this is easier to do if the firm recruits and selects new employees based upon V,R,I,N. This would require devising a method of hiring people for SCA, not simply to do a job. Therefore recruitment policies and practices may have to be revised to go beyond matching an applicant's $\mathrm{CV}$ to a position description. Interview questions, for example, could be tailored to better evaluate applicants against SCA criteria. This change in selection would give the training specialists employees who would be more easily deployed for the firm's competitive advantage through training once they have been hired.

Below are sixteen practical suggestions for designing and delivering learning and professional development initiatives aligned with the criteria for building CA.

- Stamp CA on induction training

Embed an 'employees are our SCA' mantra as opposed to the 'employees are our great asset.' Have the CEO attend group inductions to reinforce the message and to explain how employees contribute to competitive advantage. Develop a couple of activities for induction sessions which encourage new hires to reflect upon and internalize how the concept relates to them and their contributions through work.

- Ignore generic solutions

If employees are to become a differentiated resource you cannot develop them through 'offthe-shelf' or 'ready-to-go' generic training packages. You (or your training partners) must design and develop mission-specific learning solutions to set the foundation for a unique employee base. Generic training packages are easy to copy; 'off-the-shelf' packages can be bought by competitors. Learning programs should be developed against the firm's RBT strategy.

- Pass up popular resources

Do not encourage employees to dance to the tune of the world's most popular business books such as 'Who moved my cheese?'; 'Blue ocean thinking' or 'The fifth discipline.' There is no advantage to be gained from knowing what everybody else knows. There are plenty of good alternatives to help you chart your own course. Uniqueness can never be achieved by learning the same ideas as everyone else. Popular business books should only be used as a starting point to develop your own approach and should be supplemented with far less well known materials.

- Partner with quality providers

Choose your training providers with care. Many providers simply re-hash materials they have been using for years because it is more cost effective for them than starting with a blank page. You want to start with a blank page. Work closely with external providers throughout the design phase to ensure the RBT message has sunk in.

- Build programs around your uniqueness

Your organization has a unique identity articulated through vision, mission and values statements; customer care standards; strategic plans; corporate culture and so forth. Harness this opportunity for building SCA by constructing learning programs around the organization's unique identity. If your organizational culture is poor then working on improving the culture before binding it to RBT is recommended.

- Involve employees in design

Do not limit input into training design to the learning team. Seek out ideas from the wider employee body through a survey, staff meetings or a couple of focus groups. Your employees have creative, original and often ingenious ideas...but nobody ever asks them.

- Revise programs to retain uniqueness

Even great programs that work just fine should be revised, not merely reviewed, annually. You can only be different by being different so learning programs need to be evolving all the time. Seek to continually raise the bar and challenge employees. 
- Avoid the classroom

Classrooms are the least effective, most boring way to train and develop people. Get into situated learning, experiential learning, volunteering, communities of practice, projectcentered learning or any of the many other more dynamic and engaging modes of facilitating learning.

- Assess what matters

Do not just assess what people have learned but how they will apply it. Train and assess for creativity, originality, innovation and inspired application of content - not just acquisition of content because that tells us little. Mix up the assessment methods too and move away from conventional written tests (especially multiple choice quizzes)

- Inculcate desired behaviors

Identify, develop and inculcate the attitudes and behaviors that drive success in your particular organization. Knowing is one thing, but acting out knowledge is what really counts. Mentoring, coaching, buddying and performance evaluation processes can all be used to help inculcate the behaviors that matter.

- Align informing documentation with CA

HR policies and codes of practice as well as other 'people' initiatives such as talent management and career planning should all align with and support your SCA training initiatives. Training initiatives alone cannot transform employees into a resource for deriving SCA - it is everybody's business.

- Cast a wide net for 'trainers'

Your trainers should include a range of employees, outside experts and community and business personalities. At the very least, these people should be making guest appearances. If every time employees attend any training event and see the same few old faces then they are not being sufficiently challenged or inspired.

- Encourage self-directed learning

Learning and growth is continuous, it is not something 'given' by training professionals to employees. Encourage a culture where people seek opportunities to seek out and direct their own learning. Support this by growing a small corporate library or subsidize subscriptions to online resources or professional associations.

- Facilitate informal learning opportunities

Informal learning can be facilitated by establishing opportunities for people to network (social events; common areas in the organization) or by setting up networking groups based upon common interests or common demographics (women; minorities; older workers). Social media and phone apps support virtual networking too.

- Train for individualism

Training programs should not seek to make everybody the same by the time the program ends. Training should seek to develop each person's individuality. This approach greatly differentiates employees and their contributions. Ensure training activities encourage individual expression and the exploration of each person's creativity.

- Build a learning community

Move away from learning being a team of people who organize learning dictated by a calendar to the organization itself being a whole learning community. A community where everyone seeks out opportunities to learn and to help all others learn. Learning should not be a business adjunct, but something at the core of everything that the business is and does. 


\section{CONCLUSION}

With RBT, as with all theories, it is easier to claim its practical applications than to explain them. Critics of RBT have been quick to point this out. While a lot of published research employs RBT as the investigative model, most is heavy on theory and light on explaining how resources transform into CA. Proving that RBT can be applied to the study of many organizational and strategic concerns to better understand them does not guide the practitioner to sculpt resources into CA producing capabilities. This paper has addressed this missing link between resources and CA by providing a guide for learning and development practitioners wanting to strategically design and deliver learning solutions, and develop organizations, which are aligned with the criteria for a CA generating resource.

\section{REFERENCES}

Abhayawansa, S. M., \& Abeysekera, I. (2008). An explanation of human capital disclosure from the resource-based perspective. Journal of Human Resource Costing and Accounting, 12(1), 51-56.

Akio, T. (2005). The critical assessment of the resource-based view of strategic management: the source of heterogeneity of the firm. Ritsumeikan International Affairs, 3, 125-150.

Alas, R., \& Sun, W. (2007). Organizational changes in Chinese companies: a resource-based view. Chinese Management Studies, 1(4), 225-242.

Andersen, J. (2012). A resource-based taxonomy of manufacturing MSME's. International Journal of Entrepreneurial Behaviour and Research, 18(1), 98-122.

Bar-Eli, M., Galily, Y., \& Israeli, A. (2008). Gaining and sustaining competitive advantage: on the strategic similarities between Maccabi Tel Aviv BC and FC Bayern München. European Journal for Sport and Society, 5(1), 73-94.

Barney, J. (1991). Firm resources and sustained competitive advantage. Journal of Management, 17(1), 99-120.

Barney, J. (1986). Organizational culture: Can it be a source of sustained competitive advantage? Academy of Management Review, 11, 656-665.

Bollinger, A.S., \& Smith, R.D. (2001). Managing organizational knowledge as a strategic asset. Journal of Knowledge Management, 5(1), 8-18.

Bourne, M., Mills, J., \& Faull, N. (2003). Operations strategy and performance: a resource -based perspective. International Journal of Operations and Production Management, 23(9), 944-946.

Campbell, J.M., \& Park, J. (2017). Extending the resource-based view: Effects of strategic orientation toward community on small business performance. Journal of Retailing and Consumer Services, 34, 302-308.

Cassia, L., \& Minola, T. (2012). Hyper-growth of SMEs: Toward a reconciliation of entrepreneurial orientation and strategic resources. International Journal of Entrepreneurial Behaviour and Research, 18(2), 179-197.

Chew, D.A.S., Yan, S., \& Cheah, C.Y.J. (2008). Core capability and competitive strategy for construction SMEs in China. Chinese Management Studies, 2(3), 203-214.

Conner, K.R. (1991). A historical comparison of resource-based theory and five schools of thought within industrial organization economics: Do we have a new theory of the firm? Journal of Management, 17(1), 121-154.

da Costa, M.F., Costa, C.E., de Angelo, C.F., \& de Moraes, W.F.A. (2018). Perceived competitive advantage of soccer clubs: a study based on the resource-based view. RAUSP Management Journal, 53(1), 23-34.

Das, T.K., \& Teng, B.S. (2000). A resource-based theory of strategic alliances. Journal of Management, 26(1), 31-61.

Davis, L., \& Hasse, S. (1999). Developing capable employees: the work activity briefing. Journal of Workplace Learning, 11(8), 298-303.

36 Journal of Applied Business and Economics Vol. 21(5) 2019 
Ellis-Chadwick, F., Doherty, N.F., \& Anastasakis, L. (2007). E-strategy in the UK retail grocery sector: a resource-based analysis. Managing Service Quality, 17(6), 702-727.

Fahy, J. (2000). The resource-based view of the firm: some stumbling-blocks on the road to understanding sustainable competitive advantage. Journal of European Industrial Training, 24(2), 94-104.

Furrer, O., Sudharshan, D., Thomas, H., \& Alexandre, M.T. (2008). Resource configurations, generic strategies and firm performance: Exploring the parallels between resource-based and competitive advantage theories in a new industry. Journal of Strategy and Management, 1(1), 15-40.

Gallego-Alvarez, I., Prado-Lorenzo, J.M., \& Garcia-Sanchez, I.M. (2011). Corporate social responsibility and innovation: a resource-based theory. Management Decision, 49(10), 1709-1727.

Grant, R.M. (1991). The resource-based theory of competitive advantage: Implications for strategy formulation. California Management Review, Spring, 114-135.

Hazen, B.T., \& Byrd, T.A. (2012). Toward creating competitive advantage with logistics information technology. International Journal of Physical Distribution and Logistics Management, 42(1), 835.

Hunt, S.D., \& Derozier, C. (2004). The normative imperatives of business and marketing strategy: grounding strategy in resource-advantage theory. Journal of Business and Industrial Marketing, 19(1), 5-22.

Hunt, S.D., \& Madhavaram, S. (2012). Managerial action and resource-advantage theory: conceptual frameworks emanating from a positive theory of competition. Journal of Business and Industrial Marketing, 27(7), 582-591.

Jack, E.P., Bedics, T.A., \& McCary, C.E. (2006). Operational challenges in the call centre industry: case study and resource-based framework. Managing Service Quality, 16(5), 477-500.

Khandekar, A., \& Sharma, A. (2005). Managing human resource capabilities for sustainable competitive advantage: an empirical analysis from Indian global organizations. Education and Training, 47(8), 628-639.

Knott, P. (2009). Integrating resource-based theory in a practice-relevant form. Journal Strategy and Management, 12(2), 163-174.

Kraaijenbrink, J., Spender, J.C., \& Groen, A. (2009), 'The resource-based view: A review and assessment of its critiques', Paper No. 21442. Munich Personal RePEc Archive. Retrieved October 1, 2016, from https://mpra.ub.uni-muenchen.de/21442/

Lewis, M., Brandon-Jones, A., Slack, N., \& Howard, M. (2010). Competing through operations and supply: The role of classic and extended resource-based advantage. International Journal of Operations and Production Management, 30(10), 1032-1058.

Lo, Y. (2012). Managerial capabilities, organizational culture and organizational performance: The resource-based perspective in Chinese logging industry. The Journal of International Management Studies, 7(1), 151-157.

Lorentz, H., Kumar, M., \& Srai, J.S. (2018), 'Managing distance in international purchasing and supply: a systematic review of literature from the resource-based view perspective. International Business Review, 27(2), 339-354.

Masakure, O., Henson, S., \& Cranfield, J. (2009). Performance of microenterprises in Ghana: a resourcebased view. Journal of Small Business and Enterprise Development, 16(3), 466-484.

McWilliams, A., \& Siegel, D. (2011). Creating and capturing value: strategic corporate social responsibility, resource-based theory, and sustainable competitive advantage. Journal of Management, 37(5), 1480-1495.

Menguc, B., \& Barker, T. (2005). Re-examining field sales unit performance: insights from the resourcebased view and dynamic capabilities performance. European Journal of Marketing, 39(7), 885909.

Mitra, A., O'Regan, N., \& Sarpong, D. (2018). Cloud resource adaption: A resource based perspective on value creation for corporate growth. Technological Forecasting and Social Change, 130, 28-38. 
Mugera, A.W. (2012). Sustained competitive advantage in agribusiness: applying the resource-based theory to human resources. International Food and Agribusiness Management Review, 15(4), $27-$ 48.

Olavarrieta, S., \& Ellinger, A.E. (1997). Resource-based theory and strategic logistics research. International Journal of Physical Distribution and Logistics Management, 27(9), 559-587.

Ooi, K.B., Teh, P.L., \& Chong, A.Y. (2009). Developing an integrated model of TQM and HRM in KM activities. Management Research News, 32(5), 477-490.

Ordanni, A., \& Rubera, G. (2008). Strategic capabilities and internet resources in procurement: A resource-based view of B-to-B buying process International Journal of Operations and Production Management, 28(1), 27-52.

Pertusa-Ortega, E. H., Molina-Azorin, J. F., \& Claver-Cortes, E. (2010). Competitive strategy, structure and firm performance: A comparison of the resource-based view and the contingency approach. Management Decision, 48(8), 1282-1303.

Porter, M. (1980). Competitive Strategy. New York: Free Press.

Porter, M. (1985). Competitive Advantage. New York: Free Press.

Pringle, C.D., \& Kroll, M.J. (1997). Why Trafalgar was won before it was fought: Lessons from resourcebased theory. The Academy of Management Executive, 11(4), 73-89.

Rumelt, R. (1984). Towards a strategic theory of the firm,' in R. Lamb (Ed.). Competitive Strategic Management, 556 - 570. Englewood Cliffs, NJ: Prentice-Hall.

Shook, C.L., Adams, G.L., Ketchen, D.J., \& Craighead, C.W. (2009). Towards a theoretical toolbox for strategic sourcing. Supply Chain Management: An International Journal, 14(1), 3-10.

Smith, K.A., Vasudevan, S.P., \& Tanniru, M.R. (1996). Organizational learning and resource-based theory: an integrative model. Journal of Organizational Change Management, 9(6), 41-53.

Stinchcombe, A.L. (2000). Social structure and organizations,' in J.A.C. Baum \& F. Dobbin (Ed.), Economics Meets Sociology in Strategic Management (Advances in Strategic Management, Volume 17), Emerald Group Publishing Ltd, pp.229-259.

Sveiby, K. E. (2001). A knowledge-based theory of the firm to guide in strategy formulation. Journal of Intellectual Capital, 2(4), 344-358.

Ulrich, D. (1991). Using human resources for competitive advantage. In R. Kilmann, I. Kilmann \& Associates (Eds.), Making Organizations Competitive, pp. 129 - 155. San Fransisco, CA: JosseyBass.

Wan, W.P., Hoskisson, R.E., Short, J.C., \& Yin, D.W. (2011). Resource-based theory and corporate diversification: Accomplishments and opportunities. Journal of Management, 37(5), 1335-1368.

Wang, L., Huang, M., \& Liu, M. (2018). How the founders' social capital affects the success of opensource projects: a resource-based view of project teams. Electronic Commerce Research and Applications, 28, 114-126.

Weissenberger-Ebil, M., \& Schenk, J. (2009). Lifeblood knowledge: dynamic relational capabilities (DRC) and knowledge for firm innovativeness and competitive advantage. Measuring Business Excellence, 13(2), 7-16.

Wernerfelt, B. (1984). A resource-based view of the firm. Strategic Management Journal, 5(2), 171-180.

Wernerfelt, B. (1995). The resource-based view of the firm: Ten years after. Strategic Management Journal, 16(3), 171-174.

Wickramasinghe, V. (2012). Influence of total quality management on human resource management practices: An exploratory study. International Journal of Quality and Reliability Management, 29(8), 836-850.

Wright, P.M., \& McMahan, G.C. (1992). Theoretical perspectives for strategic human resource management. Journal of Management, 18(2), 295-320.

Wright, P.M., McMahan, G.C., \& McWilliams, A. (1992). Human resources as a sustained competitive advantage: a resource based perspective. Working paper, Department of Management, Texas A\&M University. 
Xu, D., Huo, B., \& Sun, L. (2014). Relationships between intra-organizational resources, supply chain integration and business performance. Industrial Management and Data Systems, 114(8), 11861206.

Yang, Y., \& Konrad, A.M. (2011). Understanding diversity management practice: Implications for institutional theory and resource-based theory. Group and Organization Management, 36(1), 638.

Zhao, Y., \& Fan, B. (2018). Exploring open government data capacity of government agency: Based on the resource-based theory. Government Information Quarterly, 35, 1-12.

Zubac, A., Hubbard, G., \& Johnson, L. (2012). Extending resource-based logic: applying the resourceinvestment concept to the firm from a payments perspective. Journal of Management, 38(6), 1867-1891. 